\title{
Combined Hepatic Resection and Radio-frequency Ablation for Patients with Colorectal Cancer Liver Metastasis: A Viable Option for Patients with a Large Number of Tumors
}

\author{
TOSHIRO MASUDA ${ }^{1,2}$, GEORGIOS ANTONIOS MARGONIS ${ }^{1}$, NIKOLAOS ANDREATOS ${ }^{1}$, JAEYUN WANG ${ }^{1}$, \\ SAMUEL WARNER ${ }^{1}$, MUHAMMAD BILAL MIRZA ${ }^{1}$, ANASTASIOS ANGELOU ${ }^{3}$, CHRISTOS DAMASKOS $^{3}$, \\ NIKOLAOS GARMPIS ${ }^{3}$, KAZUNARI SASAKI ${ }^{1}$, JIN HE ${ }^{1}$, KATSUNORI IMAI ${ }^{2}$, YO-ICHI YAMASHITA ${ }^{2}$, \\ CHRISTOPHER L. WOLFGANG ${ }^{1}$, HIDEO BABA ${ }^{2}$ and MATTHEW J. WEISS ${ }^{1}$ \\ ${ }^{1}$ Department of Surgery, Johns Hopkins University School of Medicine, Baltimore, MD, U.S.A.; \\ ${ }^{2}$ Department of Gastroenterological Surgery, Graduate School of Life Sciences, \\ Kumamoto University, Kumamoto, Japan; \\ ${ }^{3}$ Second Department of Propedeutic Surgery, "Laiko" General Hospital, \\ Medical School, National and Kapodistrian University of Athens, Athens, Greece
}

\begin{abstract}
Background/Aim: Radiofrequency ablation (RFA) is thought to result in inferior prognosis than hepatic resection among patients with colorectal liver metastasis (CRLM). However, resection plus RFA may be an option for patients with a large number of tumors ( $\geq 4$ liver lesions) and borderline resectability. Materials and Methods: A total of 717 patients with CRLM who underwent hepatic resection +/- RFA at two tertiary institutions between 09/01/2000-12/01/2015 were eligible for inclusion in this study. Results: Among patients with $<4$ lesions $(n=568)$, OS in the resection + RFA group $(n=48)$ was significantly worse than in the resection alone group ( $n=520$ ) (5-year OS: $34.4 \%$ versus $58.9 \%, p=0.007$ ). Conversely, in patients with $\geq 4$ lesions, $O S$ in the resection + RFA ( $n=68)$ and resection alone $(n=81)$ groups were not significantly different (5-year OS: $31.9 \%$ versus $34.1 \%$, $p=0.48$ ). In patients with $<4$ lesions, carcinoembryonic antigen (CEA) $\geq 30 \mathrm{ng} / \mathrm{ml}$, extrahepatic metastasis, preoperative chemotherapy and resection + RFA were independently associated with poor prognosis. Interestingly, in patients with
\end{abstract}

This article is freely accessible online.

Correspondence to: Matthew J. Weiss, MD, Assistant Professor of Surgery and Oncology, Surgical Director, Pancreas Cancer Multidisciplinary Clinic, Surgical Director, Liver Cancer Multidisciplinary Clinic, Program Director, Surgical Oncology Fellowship, Johns Hopkins University, 600 N. Wolfe Street, Halsted 608, Baltimore, MD 21287, USA. Tel: +1 4106143368, Fax: +1 443 9927305, e-mail: mweiss5@jhmi.edu

Key Words: Colorectal cancer liver metastasis, hepatic resection, radio-frequency ablation. $\geq 4$ lesions, positive primary lymph nodes, KRAS mutation, $C E A \geq 30 \mathrm{ng} / \mathrm{ml}$ and extrahepatic metastasis were independent predictors of poor prognosis; however, the combination of hepatic resection with RFA was not associated with worse survival ( $p=0.93)$. Conclusion: Although surgeons should always strive for $R O$ resection when feasible, combined resection and RFA may be a viable alternative for CRLM patients with a large number of tumors.

Currently, the principal treatment strategy for patients with colorectal cancer liver metastasis (CRLM) is systemic chemotherapy, while hepatic resection can further improve survival in carefully selected patients (1-5). On the contrary, many reports concur that radio-frequency ablation (RFA) results in inferior outcomes than hepatic resection in patients with CRLM and should only be employed when surgical resection cannot be performed (6-9).

Nonetheless, the presence of extensive metastatic tumor number in the liver, (especially four or more lesions) often precludes a curative hepatic resection due to either technical challenges or inadequate remnant liver function and is a wellknown poor prognostic factor (4, 5, 10-12). In fact, historically, specifically $\geq 4$ CRLM, was considered to be a contraindication for liver resection $(13,14)$. Similarly, a study on a contemporary cohort (treated after 2005) demonstrated that the prognosis of patients with $\geq 4$ CRLM who undergo surgery has not improved despite the development of modern chemotherapies (14). Interestingly, our group and others have demonstrated that hepatectomy + RFA may achieve long-term outcomes that are comparable to hepatectomy alone $(15,16)$.

Nonetheless, the impact of combined resection and RFA on survival among patients with different levels of tumor number 
Table I. Baseline characteristics of colorectal cancer liver metastasis patients with $<4$ and $\geq 4$ tumors.

\begin{tabular}{|c|c|c|c|}
\hline & $\begin{array}{c}\text { Patients with } \\
\text { tumors }<4 \\
(n=568)\end{array}$ & $\begin{array}{l}\text { Patients with } \\
\text { tumors } \geq 4 \\
(n=149)\end{array}$ & $p$-Value \\
\hline Age, mean & $59.6 \pm 12.5$ & $57.7 \pm 11.6$ & 0.09 \\
\hline \multicolumn{4}{|l|}{ Gender } \\
\hline Male & $342(60.2 \%)$ & $88(59.1 \%)$ & \multirow[t]{2}{*}{0.85} \\
\hline Female & $226(39.8 \%)$ & $61(40.9 \%)$ & \\
\hline \multicolumn{4}{|l|}{ Primary tumor location } \\
\hline Colon & $419(73.8 \%)$ & $114(76.5 \%)$ & \multirow[t]{2}{*}{0.53} \\
\hline Rectum & $149(26.2 \%)$ & $35(23.5 \%)$ & \\
\hline \multicolumn{4}{|l|}{ Primary N status } \\
\hline Negative & $184(32.4 \%)$ & $52(34.9 \%)$ & \multirow[t]{2}{*}{0.56} \\
\hline Positive & $384(67.6 \%)$ & $97(65.1 \%)$ & \\
\hline \multicolumn{4}{|l|}{$\begin{array}{l}\text { Concurrent primary } \\
\text { tumor resection }\end{array}$} \\
\hline Yes & $126(22.2 \%)$ & $30(20.1 \%)$ & \multirow[t]{2}{*}{0.66} \\
\hline No & $442(77.8 \%)$ & $119(79.9 \%)$ & \\
\hline \multicolumn{4}{|l|}{ KRAS mutation* } \\
\hline Mutant & $151(38.0 \%)$ & $37(38.1 \%)$ & \multirow[t]{2}{*}{$>0.99$} \\
\hline Wild & $246(62.0 \%)$ & $60(61.9 \%)$ & \\
\hline $\mathrm{CEA}(\mathrm{ng} / \mathrm{ml})^{* *}$ & $35.3 \pm 122.4$ & $84.4 \pm 607.2$ & 0.10 \\
\hline \multicolumn{4}{|l|}{ Extrahepatic metastasis } \\
\hline Present & $54(9.5 \%)$ & $13(8.7 \%)$ & \multirow[t]{2}{*}{0.87} \\
\hline Absent & $514(90.5 \%)$ & $136(91.3 \%)$ & \\
\hline \multicolumn{4}{|l|}{ Preoperative chemotherapy } \\
\hline Yes & $395(69.5 \%)$ & $127(85.2 \%)$ & \multirow[t]{2}{*}{$<0.001$} \\
\hline No & $173(30.5 \%)$ & $22(14.8 \%)$ & \\
\hline Tumor size $(\mathrm{cm})$ & $3.19 \pm 2.26$ & $2.94 \pm 2.07$ & 0.22 \\
\hline Tumor number, median (IQR) & $1(1-2)$ & $5(4-8)$ & $<0.001$ \\
\hline \multicolumn{4}{|l|}{ Combination of RFA } \\
\hline Yes & $48(8.5 \%)$ & $68(45.6 \%)$ & \multirow[t]{2}{*}{$<0.001$} \\
\hline No & $520(91.5 \%)$ & $81(54.4 \%)$ & \\
\hline
\end{tabular}

*Data obtained from 494 patients. **Data obtained from 593 patients.

has not been well-studied. As such, we aimed to compare the overall survival of patients who underwent hepatic resection plus RFA and hepatic resection alone according to tumor number (with the presence of $<4$ lesions defined as small number and the presence of $\geq 4$ liver lesions as big number); furthermore, factors associated with poor survival among patients with $<4$ and $\geq 4$ liver lesions were also assessed.

\section{Materials and Methods}

Study design. We performed a retrospective study that included data from patients with CRLM who underwent hepatic resection with or without RFA at two institutions: Johns Hopkins Hospital (eligible patients underwent surgery between January 2003 and October 2015) and Kumamoto University (eligible patients underwent surgery between September 2000 and December 2015). Surgical indications and technical details of the procedures employed at both institutions have been described previously (16-20). At Johns Hopkins University, hepatic resection + RFA was selected when at
Table II. Tumor number and size treated with hepatic resection and RFA.

\begin{tabular}{lccc}
\hline & $\begin{array}{c}\text { Patients with } \\
\text { tumors }<4 \\
(\mathrm{n}=568)\end{array}$ & $\begin{array}{c}\text { Patients with } \\
\text { tumors } \geq 4 \\
(\mathrm{n}=149)\end{array}$ & $p$-Value \\
\hline $\begin{array}{l}\text { Tumor number treated with } \\
\text { hepatic resection, median }\end{array}$ & $1(1-2)$ & $4(2-7)$ & $<0.001$ \\
$\begin{array}{l}\text { Tumor size treated with } \\
\text { hepatic resection, mean (cm) } \\
\text { Tumor number treated with }\end{array}$ & $3.19 \pm 2.26$ & $2.94 \pm 2.07$ & 0.22 \\
$\begin{array}{l}\text { RFA, median } \\
\text { Tumor size treated with }\end{array}$ & $1(1-2)$ & $2.5(1-4)$ & $<0.001$ \\
\begin{tabular}{l} 
RFA, mean (cm) \\
\hline
\end{tabular} & $1.25 \pm 0.75$ & $1.59 \pm 1.22$ & 0.10 \\
\hline
\end{tabular}

least one hepatic tumor was considered unresectable because of its location, inadequate liver remnant, proximity of tumor to major vascular structure, or presence of medical comorbidities that precluded major hepatic resection (16). At Kumamoto University, hepatic resection + RFA was performed in patients with initially unresectable multiple metastases and had already received chemotherapy for CRLM (19).

Information on preoperative patient characteristics including age, gender, primary tumor location (colon $v s$. rectum), primary lymph node metastasis $(\mathrm{N})$ status, concurrent primary tumor resection, KRAS mutation status, serum carcinoembryonic antigen (CEA) level, presence of extrahepatic metastasis, administration of preoperative chemotherapy, size of the largest liver metastasis and number of CRLM were collected for each included patient. Data on tumor size and number were obtained with the aid of preoperative CT or MRI; information on the size and number of tumors treated with hepatic resection and RFA was also collected, based on the findings of pathology. Patients' survival data after hepatic resection were obtained. This study was approved by both the Johns Hopkins University and Kumamoto University Institutional Review Boards.

Statistical analysis. Patient age, serum CEA level and tumor size were expressed as means \pm standard deviation and were compared using the Student's $t$-test, while tumor number was expressed as a median with interquartile range (IQR) and were compared using the Mann-Whitney $U$-test. Overall survival rates were calculated with the Kaplan-Meier method and compared with the log rank test. Univariate analyses were performed using the chi square test or Fisher's exact probability test for categorical values and the Student's $t$-test for continuous variables. All factors that were shown to be significant in univariate analysis were incorporated into the multivariate analysis, as was the main variable of interest (performance of RFA in conjunction with hepatic resection). A $p$-value $<0.05$ was considered statistically significant. All statistical analyses were performed using Statview software (SAS Institute, Cary, NC, USA).

\section{Results}

A total of 717 patients from both institutions were included in the final study cohort. The frequency with which hepatic resection was performed in combination with RFA was $45.6 \%$ in patients with $\geq 4$ lesions, compared to $8.5 \%$ in 
Table III. Characteristics of patients treated with hepatic resection and hepatic resection + RFA in patients with tumors $<4(n=568)$.

\begin{tabular}{|c|c|c|c|}
\hline Factors & $\begin{array}{l}\text { Hepatic } \\
\text { resection } \\
(\mathrm{n}=520)\end{array}$ & $\begin{array}{c}\text { Hepatic } \\
\text { resection } \\
+ \text { RFA } \\
(n=48)\end{array}$ & $p$-Value \\
\hline Age, mean & $59.8 \pm 12.5$ & $57.6 \pm 12.0$ & 0.23 \\
\hline \multicolumn{4}{|l|}{ Gender } \\
\hline Male & $311(59.8 \%)$ & $31(64.6 \%)$ & \multirow[t]{2}{*}{0.54} \\
\hline Female & $209(40.2 \%)$ & $17(35.4 \%)$ & \\
\hline \multicolumn{4}{|c|}{ Primary tumor location } \\
\hline Colon & $378(72.7 \%)$ & $41(85.4 \%)$ & \multirow[t]{2}{*}{0.06} \\
\hline Rectum & $142(27.3 \%)$ & $7(14.6 \%)$ & \\
\hline \multicolumn{4}{|l|}{ Primary N status } \\
\hline Negative & $168(32.3 \%)$ & $16(33.3 \%)$ & \multirow[t]{2}{*}{0.87} \\
\hline Positive & $352(67.7 \%)$ & $32(66.7 \%)$ & \\
\hline \multicolumn{4}{|c|}{$\begin{array}{l}\text { Concurrent primary } \\
\text { tumor resection }\end{array}$} \\
\hline Yes & $117(22.5 \%)$ & $9(18.8 \%)$ & \multirow[t]{2}{*}{0.71} \\
\hline No & $403(77.5 \%)$ & $39(81.2 \%)$ & \\
\hline \multicolumn{4}{|l|}{ KRAS mutation* } \\
\hline Mutant & $136(38.3 \%)$ & $15(35.7 \%)$ & \multirow[t]{2}{*}{0.87} \\
\hline Wild & $219(61.7 \%)$ & $27(64.3 \%)$ & \\
\hline CEA $(\mathrm{ng} / \mathrm{ml}) * *$ & $36.6 \pm 127.2$ & $22.6 \pm 52.4$ & 0.48 \\
\hline \multicolumn{4}{|c|}{ Extrahepatic metastasis } \\
\hline Present & $50(9.6 \%)$ & $4(8.3 \%)$ & \multirow[t]{2}{*}{$>0.99$} \\
\hline Absent & $470(90.4 \%)$ & $44(91.7 \%)$ & \\
\hline \multicolumn{4}{|c|}{ Preoperative chemotherapy } \\
\hline Yes & $353(67.9 \%)$ & $42(87.5 \%)$ & \multirow[t]{2}{*}{0.005} \\
\hline No & $167(32.1 \%)$ & $6(12.5 \%)$ & \\
\hline Tumor size $(\mathrm{cm})$ & $3.2 \pm 2.3$ & $2.8 \pm 1.7$ & 0.20 \\
\hline $\begin{array}{l}\text { Tumor number, } \\
\text { median (IQR) }\end{array}$ & $1(1-2)$ & $2(2-3)$ & $<0.001$ \\
\hline
\end{tabular}

*Data obtained from 397 patients. **Data obtained from 347 patients.

patients with $<4$ lesions $(p<0.001)$. The administration of preoperative chemotherapy was also significantly more common among patients with $\geq 4$ lesions, than in patients with $<4$ lesions $(p<0.001)$. Patient age, gender, primary tumor location, primary tumor lymph node status, concurrent primary tumor resection, KRAS mutation status, serum CEA level, the presence of extrahepatic metastasis and tumor size were not significantly different between patients with $<4$ and $\geq 4$ lesions (Table I).

Tumor number of patients treated with both hepatic resection $(p<0.001)$ and RFA $(p<0.001)$ were significantly higher in those with tumors $\geq 4$ than those with $<4$. Tumor size treated with hepatic resection $(p=0.22)$ or $\operatorname{RFA}(p=0.10)$ were not significantly different between the groups (Table II).

In patients with tumors $<4 \quad(\mathrm{n}=568)$, preoperative chemotherapy $(p=0.005)$ and tumor number $(<0.001)$ were higher in the group of hepatic resection + RFA even though all patients had three or less tumors (Table III). Patient age, gender, primary tumor location, primary $\mathrm{N}$ status, concurrent
Table IV. Characteristics of patients treated with hepatic resection and hepatic resection + RFA in patients with tumors $\geq 4$ ( $n=149)$.

\begin{tabular}{|c|c|c|c|}
\hline Factors & $\begin{array}{l}\text { Hepatic } \\
\text { resection } \\
(\mathrm{n}=81)\end{array}$ & $\begin{array}{c}\text { Hepatic } \\
\text { resection } \\
+ \text { RFA } \\
(n=68)\end{array}$ & $p$-Value \\
\hline Age, mean & $56.9 \pm 12.4$ & $58.7 \pm 10.6$ & 0.37 \\
\hline \multicolumn{4}{|l|}{ Gender } \\
\hline Male & $45(55.6 \%)$ & $43(63.2 \%)$ & \multirow[t]{2}{*}{0.40} \\
\hline Female & $36(44.4 \%)$ & $25(36.8 \%)$ & \\
\hline \multicolumn{4}{|c|}{ Primary tumor location } \\
\hline Colon & $58(71.6 \%)$ & $56(82.4 \%)$ & \multirow[t]{2}{*}{0.17} \\
\hline Rectum & $23(28.4 \%)$ & $12(17.6 \%)$ & \\
\hline \multicolumn{4}{|l|}{ Primary $\mathrm{N}$ status } \\
\hline Negative & $30(37.0 \%)$ & $22(32.4 \%)$ & \multirow[t]{2}{*}{0.61} \\
\hline Positive & $51(63.0 \%)$ & $46(67.6 \%)$ & \\
\hline \multicolumn{4}{|c|}{$\begin{array}{l}\text { Concurrent primary } \\
\text { tumor resection }\end{array}$} \\
\hline Yes & $20(24.7 \%)$ & $10(14.7 \%)$ & \multirow[t]{2}{*}{0.008} \\
\hline No & $61(75.3 \%)$ & $58(85.3 \%)$ & \\
\hline \multicolumn{4}{|l|}{ KRAS mutation* } \\
\hline Mutant & $17(33.3 \%)$ & $20(43.5 \%)$ & \multirow[t]{2}{*}{0.40} \\
\hline Wild & $34(66.7 \%)$ & $26(56.5 \%)$ & \\
\hline $\mathrm{CEA}(\mathrm{ng} / \mathrm{ml}) * *$ & $134.4 \pm 831.8$ & $28.6 \pm 89.4$ & 0.33 \\
\hline \multicolumn{4}{|c|}{ Extrahepatic metastasis } \\
\hline Present & $6(7.4 \%)$ & $7(10.3 \%)$ & \multirow[t]{2}{*}{0.57} \\
\hline Absent & $75(92.6 \%)$ & $61(89.7 \%)$ & \\
\hline \multicolumn{4}{|c|}{ Preoperative chemotherapy } \\
\hline Yes & $66(81.5 \%)$ & $61(89.7 \%)$ & \multirow[t]{2}{*}{0.17} \\
\hline No & $15(18.5 \%)$ & $7(10.3 \%)$ & \\
\hline Tumor size (cm) & $3.1 \pm 2.4$ & $2.8 \pm 1.6$ & 0.45 \\
\hline $\begin{array}{l}\text { Tumor number, } \\
\text { median (IQR) }\end{array}$ & $5(4-7)$ & $5(4-10)$ & 0.10 \\
\hline
\end{tabular}

*Data obtained from 97 patients. **Data obtained from 82 patients.

primary tumor resection, KRAS mutation, serum CEA level, extrahepatic metastasis and tumor size were not different between the groups. In patients with tumors $\geq 4 \quad(n=149)$, concurrent primary tumor resection was lower in the hepatic resection + RFA group $(p=0.008)$ (Table IV). Patient age, gender, primary tumor location, primary $\mathrm{N}$ status, KRAS mutation, serum CEA level, extrahepatic metastasis, preoperative chemotherapy, tumor size and median tumor number were not different between the groups.

Overall survival of patients who underwent hepatic resection with and without RFA. Patients who underwent hepatic resection + RFA ( $n=116)$ had a significantly worse prognosis than those who underwent hepatic resection alone $(\mathrm{n}=601)(1,3$, and 5-year overall survival: $89.2 \%, 53.2 \%$ and $33.1 \%$ versus $94.9 \%, 70.9 \%$ and $55.3 \%$, respectively; $p<0.001$ ) (Figure 1). Similarly, among patients with fewer than 4 hepatic lesions, overall survival in the group that underwent hepatic resection + RFA $(n=48)$ was significantly 
(\%)

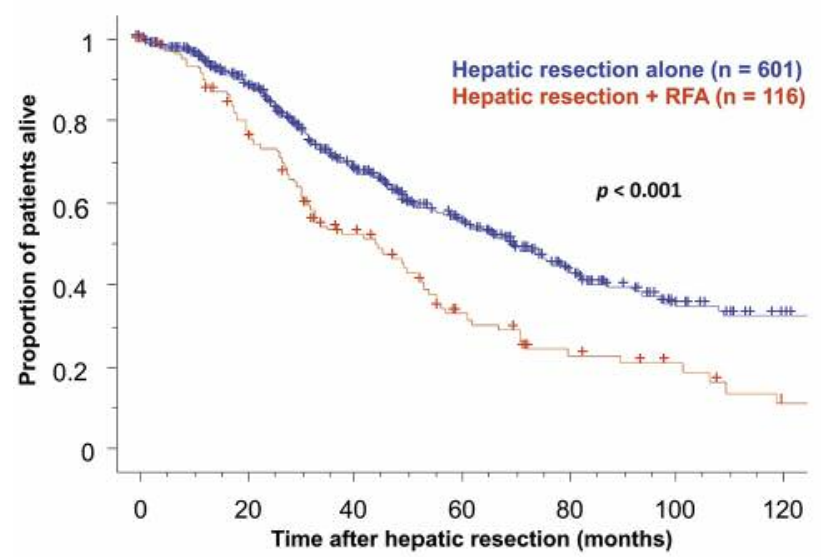

Figure 1. Overall survival of CRLM patients who underwent hepatic resection plus RFA and hepatic resection alone. Overall survival of CRLM patients who underwent hepatic resection $+R F A(n=116)$ was significantly worse than those who underwent hepatic resection alone $(n=601)(1-, 3-$, and 5 -year overall survival: $89.2 \%, 53.2 \%$ and $33.1 \%$ versus $94.9 \%, 70.9 \%$ and $55.3 \%$, respectively; $p<0.001)$.

worse than in the group that underwent hepatic resection alone $(\mathrm{n}=520)(1,3$, and 5-year overall survival: $93.3 \%$, $52.8 \%$ and $34.4 \%$ versus $94.5 \%, 72.3 \%$ and $58.9 \%$, respectively; $p=0.007$ ) (Figure $2 \mathrm{~A}$ ). On the other hand, in patients with $\geq 4$ lesions, overall survival in the groups that underwent hepatic resection + RFA $(n=68)$ and hepatic resection alone $(\mathrm{n}=81)$ were not found to be significantly different $(1,3$, and 5-year overall survival: $87.9 \%, 53.4 \%$ and $31.9 \%$ versus $98.7 \%, 64.3 \%$ and $34.1 \%$, respectively; $p=0.48$ ) (Figure 2B).

Preoperative predictors of survival for patients with $<4$ and $\geq 4$ hepatic lesions. For patients with $<4$ hepatic lesions, history of positive primary lymph nodes $(p=0.034)$, CEA $\geq 30 \mathrm{ng} / \mathrm{ml}(p<0.001)$, presence of extrahepatic metastasis $(p=0.004)$, administration of preoperative chemotherapy $(p=0.005)$ and combination of hepatic resection with RFA $(p<0.001)$ were predictors of poor prognosis in univariate analysis. In multivariate analysis, CEA $\geq 30 \mathrm{ng} / \mathrm{ml}(p<0.001)$, presence of extrahepatic metastasis $(p=0.01)$, administration of preoperative chemotherapy $(p=0.03)$ and combination of hepatic resection with RFA $(p<0.001)$ were independently associated with poor prognosis (Table V).

Conversely, for patients with $\geq 4$ hepatic lesions, history of positive primary lymph nodes $(p=0.004)$, CEA $\geq 30 \mathrm{ng} / \mathrm{ml}$ $(p=0.02)$, presence of extrahepatic metastasis $(p=0.01)$, administration of preoperative chemotherapy $(p=0.024)$ and the presence of KRAS mutation $(p<0.001)$ were predictors of poor prognosis in univariate analysis. Subsequently, we

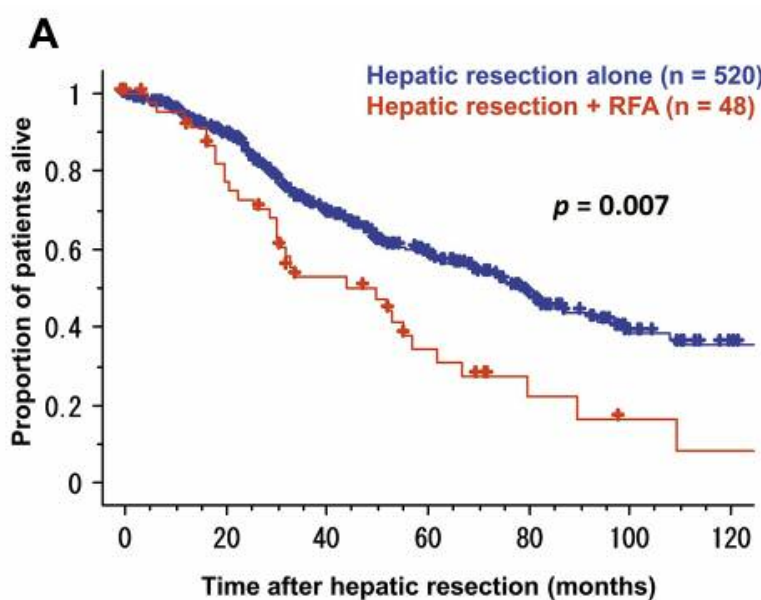

\section{B}

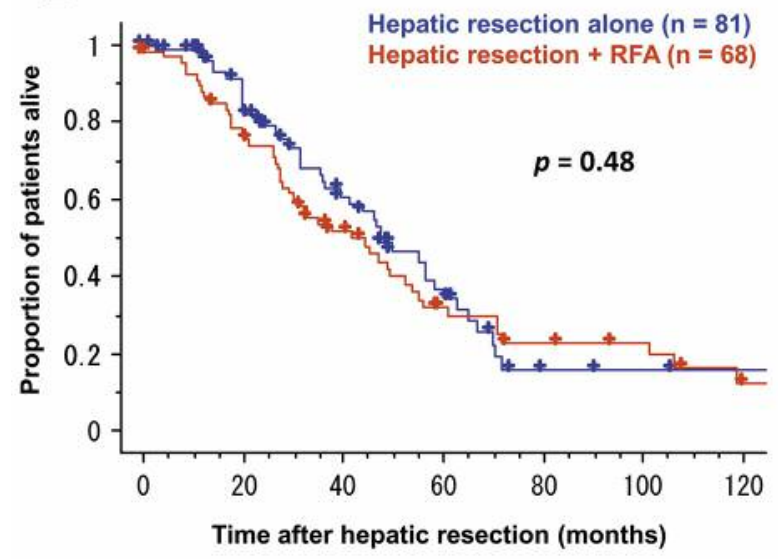

Figure 2. Overall survival of CRLM patients with tumors $<4$ (A) and $\geq 4$ (B) who underwent hepatic resection + RFA and hepatic resection alone. In patients with tumors $<4$, overall survival of patients who underwent hepatic resection $+R F A(n=48)$ was significantly worse than those who underwent hepatic resection alone $(n=520)(1-, 3-$, and 5year overall survival: $93.3 \%, 52.8 \%$ and $34.4 \%$ versus $94.5 \%, 72.3 \%$ and $58.9 \%$, respectively; $p=0.007)(A)$. In patients with tumors $\geq 4$, overall survival of patients who underwent hepatic resection $+R F A$ $(n=68)$ and hepatic resection alone $(n=81)$ were not significantly different $(1,3$, and 5-year overall survival: $87.9 \%, 53.4 \%$ and $31.9 \%$ versus $98.7 \%, 64.3 \%$ and $34.1 \%$, respectively; $p=0.48)(B)$.

conducted a multivariate analysis that included all aforementioned significant prognostic factors in addition to the concurrent performance of hepatic resection and RFA. Importantly, history of positive primary lymph nodes $(p=0.044)$, the presence of KRAS mutation $(p<0.001)$, CEA $\geq 30 \mathrm{ng} / \mathrm{ml} \quad(p=0.044)$ and the presence of extrahepatic metastasis $(p<0.001)$ were shown to be independent predictors of poor prognosis, while the combination of hepatic resection with RFA did not appear to be associated with worse survival $(p=0.93)$ (Table VI). 
Table V. Preoperative prognostic factors for patients with tumors $<4$ ( $n=568)$.

\begin{tabular}{|c|c|c|c|}
\hline & \multirow{2}{*}{$\begin{array}{c}\text { Univariate } \\
p \text {-Value }\end{array}$} & \multicolumn{2}{|c|}{ Multivariate } \\
\hline & & Hazard ratio $(95 \% \mathrm{CI})$ & $p$-Value \\
\hline Age $(\geq 65)$ & 0.08 & & \\
\hline Gender $(\mathrm{M})$ & 0.29 & & \\
\hline Primary tumor location (rectum) & 0.10 & & \\
\hline Primary N (positive) & 0.034 & $1.27(0.91-1.78)$ & 0.16 \\
\hline Concurrent primary tumor resection (Yes) & 0.71 & & \\
\hline KRAS mutation (mutant) & 0.47 & & \\
\hline $\mathrm{CEA}(\geq 30 \mathrm{ng} / \mathrm{ml})$ & $<0.001$ & $2.12(1.51-2.98)$ & $<0.001$ \\
\hline Extrahepatic metastasis (present) & 0.004 & $1.84(1.15-2.93)$ & 0.01 \\
\hline Preoperative chemotherapy (Yes) & 0.005 & $1.45(1.03-2.05)$ & 0.03 \\
\hline Tumor size $(\geq 3 \mathrm{~cm})$ & 0.07 & & \\
\hline Combination of RFA (Yes) & $<0.001$ & $1.89(1.24-2.87)$ & 0.003 \\
\hline
\end{tabular}

Table VI. Preoperative prognostic factors for patients with tumors $\geq 4$ ( $n=149$ ).

\begin{tabular}{|c|c|c|c|}
\hline & \multirow{2}{*}{$\begin{array}{c}\text { Univariate } \\
p \text {-Value }\end{array}$} & \multicolumn{2}{|c|}{ Multivariate } \\
\hline & & Hazard ratio $(95 \% \mathrm{CI})$ & $p$-Value \\
\hline Age $(\geq 65)$ & 0.12 & & \\
\hline Gender $(\mathrm{M})$ & 0.81 & & \\
\hline Primary tumor location (rectum) & 0.38 & & \\
\hline Primary N (positive) & 0.004 & $1.98(1.02-3.86)$ & 0.044 \\
\hline Concurrent primary tumor resection (Yes) & 0.81 & & \\
\hline KRAS mutation (mutant) & $<0.001$ & $4.02(1.91-8.40)$ & $<0.001$ \\
\hline $\mathrm{CEA}(\geq 30 \mathrm{ng} / \mathrm{ml})$ & 0.02 & $2.36(1.02-5.43)$ & 0.044 \\
\hline Extrahepatic metastasis (present) & 0.01 & $4.93(2.04-11.9)$ & $<0.001$ \\
\hline Preoperative chemotherapy (Yes) & 0.024 & $2.92(0.92-9.26)$ & 0.07 \\
\hline Tumor size $(\geq 3 \mathrm{~cm})$ & 0.14 & & \\
\hline Combination of RFA (Yes) & 0.48 & $1.03(0.54-1.96)$ & 0.93 \\
\hline
\end{tabular}

Prognosis of patients without extrahepatic metastases and with $\geq 4$ hepatic lesions who underwent hepatic resection + $R F A$ vs. hepatic resection alone. We performed an additional survival analysis of patients with $\geq 4$ hepatic lesions treated with hepatic resection with or without RFA, after first excluding patients with extrahepatic metastases (Figure 3 ). Importantly, the overall survival of patients who underwent hepatic resection + RFA $(n=61)$ was not found to differ significantly from that of patients who underwent hepatic resection alone $(\mathrm{n}=75)(p=0.66)$.

\section{Discussion}

This study was primarily conducted to evaluate the prognostic implications of combining RFA with hepatic resection among patients with a large number of liver metastases. Importantly, patients with $\geq 4$ hepatic lesions were shown to have similar prognosis, irrespective of whether they were treated with hepatic resection + RFA or hepatic resection alone; the

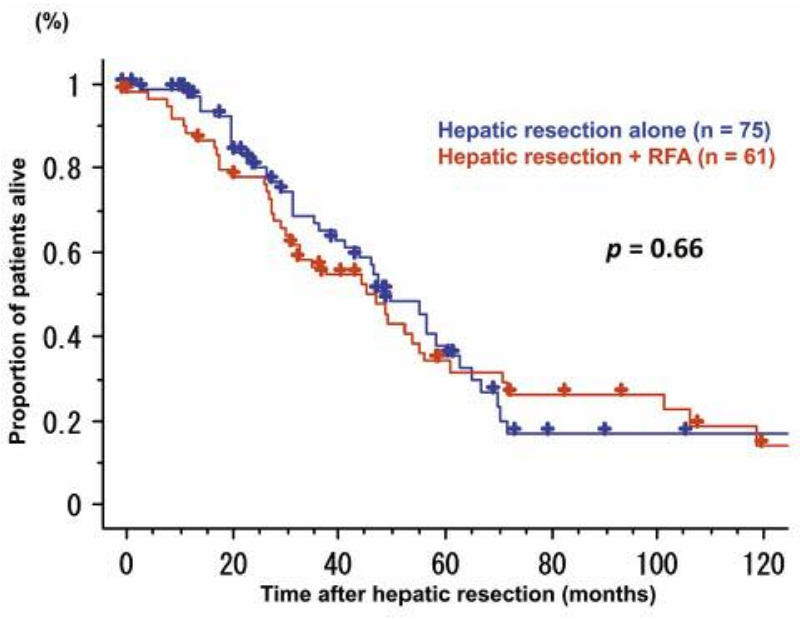

Figure 3. Overall survival of CRLM patients with tumors $\geq 4$ without extrahepatic metastases who underwent hepatic resection + RFA or hepatic resection alone. The 5-year overall survival of hepatic resection $+R F A(n=61)$ and hepatic resection alone $(n=75)$ were $34.0 \%$ and $35.4 \%$, respectively $(p=0.66)$. 
exclusion of patients with extrahepatic metastasis from the cohort confirmed these findings. However, combined hepatic resection and RFA was a poor prognostic factor in patients with $<4$ hepatic lesions. Additional factors that may influence prognosis among patients with either $<4$ or $\geq 4$ hepatic lesions were also investigated, in an attempt to aid treatment selection in these patient groups.

Importantly, our analysis indicated that the presence of extensive metastatic tumor number in the liver may neutralize the negative prognostic implications associated with the use of RFA (21). Indeed, the presence of 4 or more hepatic tumors has previously been associated with especially poor prognosis and early recurrence in patients undergoing hepatic resection for CRLM $(10-12,22,23)$. As such, it is possible that patients with 4 or more lesions have such aggressive underlying disease biology that technical considerations (use of combined resection and RFA vs. resection alone) have a comparably minor impact on outcomes. Similarly, previous studies from our group and others have shown that the technical adequacy of a resection as measured by the achievement of negative surgical margins has no measurable impact on outcomes among high-risk patients with aggressive disease biology (24, 25). However, surgeons should still strive for an R0 resection when technically feasible, as the present study lacks the statistical power to conclusively prove the equivalence of combined resection and RFA vs. hepatic resection alone (26). Our findings are instead more applicable to borderline cases, where an R0 resection may be feasible, but at the cost of performing extremely aggressive surgery, that may, in turn result in post-hepatectomy liver failure or increase the risk for postoperative recurrence by excessively stimulating liver regeneration (27-29). As RFA is considered to be more successful in sparing liver parenchyma and preserving residual liver function than extensive resection, the combined use of resection and RFA may be a viable alternative for patients with high tumor burden and borderline resectability (30).

We also attempted to quantify the relative importance of various prognostic factors among patients with $<4$ and $\geq 4$ hepatic lesions with the use of multivariable analysis. In line with previous studies, the presence of extrahepatic metastasis was shown to be an adverse prognostic factor in both groups (31). Nonetheless, recent studies suggest that local therapy for liver metastases might still benefit patients with extrahepatic disease; as such, the use of RFA with or without concurrent resection might be a reasonable option in this setting $(32,33)$. Previous studies have also identified a high serum CEA level as a predictor of poor prognosis in CRLM patients $(12,34-$ 37). This finding was confirmed in the present study for all patients, irrespective of tumor number. The administration of preoperative chemotherapy was also a poor prognostic factor in patients with fewer than 4 hepatic lesions, which likely reflects the fact that preoperative chemotherapy is commonly administered to patients with advanced, high-risk disease.
The present study had several limitations. The analysis was based on retrospective data from two distinct surgical cohorts; as such, a degree of selection bias was unavoidable, especially since tumor number is an important determinant of treatment among patients with CRLM. Nonetheless, this limitation is inherent to retrospective studies and we attempted to mitigate it by controlling for possible confounders with the aid of multivariable analysis. Furthermore, treatment indications and the composition of each patient population differed somewhat between the two institutional cohorts. More importantly, the number of patients with 4 hepatic lesions or more was limited thus reducing the statistical power of our analysis. As such, our findings would certainly benefit from validation in larger institutional cohorts.

In conclusion, our findings indicate that combined resection and RFA may be a viable option for local treatment in patients with CRLM and a large number of liver lessions. Although in the absence of contradictory data from clinical trials surgeons should strive for complete disease extirpation if feasible, these findings underscore the utility of RFA among patients with borderline resectability and emphasize the primacy of tumor biology over technical considerations in determining the outcomes of patients with advanced disease.

\section{Conflicts of Interest}

The Authors have no conflicts of interest to declare.

\section{References}

1 Araujo RL, Gonen M and Herman P: Chemotherapy for patients with colorectal liver metastases who underwent curative resection improves long-term outcomes: systematic review and meta-analysis. Ann Surg Onc 22: 3070-3078, 2015.

2 Pikoulis E, Margonis GA, Andreatos N, Sasaki K, Angelou A, Polychronidis G, Pikouli A, Riza E, Pawlik TM and Antoniou E: Prognostic role of BRAF mutations in colorectal cancer liver metastases. Ant Res 36: 4805-4811, 2016.

3 Andreatos N, Ronnekleiv-Kelly S, Margonis GA, Sasaki K, Gani F, Amini N, Wilson A and Pawlik TM: From bench to bedside: Clinical implications of KRAS status in patients with colorectal liver metastasis. Surg Onc 25: 332-338, 2016.

4 Jones RP, Kokudo N, Folprecht G, Mise Y, Unno M, Malik HZ, Fenwick SW and Poston GJ: Colorectal liver metastases: A critical review of state of the art. Liver Cancer 6: 66-71, 2016.

5 Adam R, De Gramont A, Figueras J, Guthrie A, Kokudo N, Kunstlinger F, Loyer E, Poston G, Rougier P, Rubbia-Brandt L, Sobrero A, Tabernero J, Teh C and Van Cutsem E: The oncosurgery approach to managing liver metastases from colorectal cancer: a multidisciplinary international consensus. The Oncologist 17: 1225-1239, 2012.

6 Park IJ, Kim HC, Yu CS, Kim PN, Won HJ and Kim JC: Radiofrequency ablation for metachronous liver metastasis from colorectal cancer after curative surgery. Ann Surg Onc 15: 227232, 2008. 
7 Ko S, Jo H, Yun S, Park E, Kim S and Seo HI: Comparative analysis of radiofrequency ablation and resection for resectable colorectal liver metastases. World Jou Gast 20: 525-531, 2014.

8 Hebbar M, Truant S, Desauw C, Sergent-Baudson G, Cattan S, Piessen G and Pruvot FR: High-dose FOLFIRI, surgery, and radiofrequency ablation for patients with unresectable liver metastases from colorectal cancer. Ant Res 33: 1603-1607, 2013.

9 Cirimbei C, Rotaru V, Chitoran E, Pavaleanu O and Cirimbei SE: Immediate and long-term results of radiofrequency ablation for colorectal liver metastases. Ant Res 37: 6489-6494, 2017.

10 Dexiang Z, Li R, Ye W, Haifu W, Yunshi Z, Qinghai Y, Shenyong Z, Bo X, Li L, Xiangou P, Haohao L, Lechi Y, Tianshu L, Jia F, Xinyu Q and Jianmin X: Outcome of patients with colorectal liver metastasis: analysis of 1,613 consecutive cases. Ann Surg Onc 19: 2860-2868, 2012.

11 Rees M, Tekkis PP, Welsh FK, O'Rourke T and John TG: Evaluation of long-term survival after hepatic resection for metastatic colorectal cancer: a multifactorial model of 929 patients. Ann Surg 247: 125-135, 2008.

12 Choti MA, Sitzmann JV, Tiburi MF, Sumetchotimetha W, Rangsin R, Schulick RD, Lillemoe KD, Yeo CJ and Cameron JL: Trends in long-term survival following liver resection for hepatic colorectal metastases. Ann Surg 235: 759-766, 2002.

13 Ballantyne GH and Quin J: Surgical treatment of liver metastases in patients with colorectal cancer. Cancer 71: 42524266, 1993.

14 Hokuto D, Nomi T, Yamato I, Yasuda S, Obara S, Yoshikawa T, Kawaguchi C, Yamada T, Kanehiro H and Nakajima Y: The prognosis of liver resection for patients with four or more colorectal liver metastases has not improved in the era of modern chemotherapy. J Surg Oncol 114: 959-965, 2016.

15 Imai K, Allard MA, Castro Benitez C, Vibert E, Sa Cunha A, Cherqui D, Castaing D, Baba $\mathrm{H}$ and Adam R: Long-term outcomes of radiofrequency ablation combined with hepatectomy compared with hepatectomy alone for colorectal liver metastases. Br J Surg 104: 570-579, 2017.

16 Sasaki K, Margonis GA, Andreatos N, Kim Y, Wilson A, Gani $\mathrm{F}$, Amini $\mathrm{N}$ and Pawlik TM: Combined resection and RFA in colorectal liver metastases: stratification of long-term outcomes. J Surg Res 206: 182-189, 2016.

17 de Jong MC, van Vledder MG, Ribero D, Hubert C, Gigot JF, Choti MA, Schulick RD, Capussotti L, Dejong CH and Pawlik TM: Therapeutic efficacy of combined intraoperative ablation and resection for colorectal liver metastases: an international, multi-institutional analysis. Journal of gastrointestinal surgery : official journal of the Society for Surgery of the Alimentary Tract 15: 336-344, 2011.

18 Gleisner AL, Choti MA, Assumpcao L, Nathan H, Schulick RD and Pawlik TM: Colorectal liver metastases: recurrence and survival following hepatic resection, radiofrequency ablation, and combined resection-radiofrequency ablation. Arch Surg 143: 1204-1212, 2008.

19 Mima K, Beppu T, Chikamoto A, Miyamoto Y, Nakagawa S, Kuroki H, Okabe H, Hayashi H, Sakamoto Y, Watanabe M, Kikuchi $\mathrm{K}$ and Baba $\mathrm{H}$ : Hepatic resection combined with radiofrequency ablation for initially unresectable colorectal liver metastases after effective chemotherapy is a safe procedure with a low incidence of local recurrence. Int J Clin Oncol 18: 847$855,2013$.
20 Beppu T, Miyamoto Y, Sakamoto Y, Imai K, Nitta H, Hayashi $\mathrm{H}$, Chikamoto A, Watanabe $\mathrm{M}$, Ishiko $\mathrm{T}$ and Baba $\mathrm{H}$ : Chemotherapy and targeted therapy for patients with initially unresectable colorectal liver metastases, focusing on conversion hepatectomy and long-term survival. Ann Surg Onc 21: S405413, 2014.

21 Abdalla EK, Vauthey JN, Ellis LM, Ellis V, Pollock R, Broglio $\mathrm{KR}$, Hess $\mathrm{K}$ and Curley SA: Recurrence and outcomes following hepatic resection, radiofrequency ablation, and combined resection/ablation for colorectal liver metastases. Ann Surg 239: 818-825; discussion 825-817, 2004.

22 Vigano L, Capussotti L, Lapointe R, Barroso E, Hubert C, Giuliante F, Ijzermans JN, Mirza DF, Elias D and Adam R: Early recurrence after liver resection for colorectal metastases: risk factors, prognosis, and treatment. A LiverMetSurvey-based study of 6,025 patients. Ann Surg Onc 21: 1276-1286, 2014.

23 Beppu T, Sakamoto Y, Hasegawa K, Honda G, Tanaka K, Kotera Y, Nitta H, Yoshidome H, Hatano E, Ueno M, Takamura H, Baba H, Kosuge T, Kokudo N, Takahashi K, Endo I, Wakabayashi G, Miyazaki M, Uemoto S, Ohta T, Kikuchi K, Yamaue $\mathrm{H}$, Yamamoto $\mathrm{M}$ and Takada T: A nomogram predicting disease-free survival in patients with colorectal liver metastases treated with hepatic resection: multicenter data collection as a Project Study for Hepatic Surgery of the Japanese Society of Hepato-Biliary-Pancreatic Surgery. J HPB Sc 19: 72-84, 2012.

24 Margonis GA, Sasaki K, Andreatos N, Kim Y, Merath K, Wagner D, Wilson A, Buettner S, Amini N, Antoniou E and Pawlik TM: KRAS mutation status dictates optimal surgical margin width in patients undergoing resection of colorectal liver metastases. Ann Surg Onc 24: 264-271, 2017.

25 Margonis GA, Sasaki K, Kim Y, Samaha M, Buettner S, Amini $\mathrm{N}$, Antoniou E and Pawlik TM: Tumor biology rather than surgical technique dictates prognosis in colorectal cancer liver metastases. J Gast Surg 20: 1821-1829, 2016.

26 Sadot E, Groot Koerkamp B, Leal JN, Shia J, Gonen M, Allen PJ, DeMatteo RP, Kingham TP, Kemeny N, Blumgart LH, Jarnagin WR and D'Angelica MI: Resection margin and survival in 2368 patients undergoing hepatic resection for metastatic colorectal cancer: surgical technique or biologic surrogate? Ann Surg 262: 476-485; discussion 483-475, 2015.

27 Andreatos N, Amini N, Gani F, Margonis GA, Sasaki K, Thompson VM, Bentrem DJ, Hall BL, Pitt HA, Wilson A and Pawlik TM: Albumin-Bilirubin Score: Predicting short-term outcomes including bile leak and post-hepatectomy liver failure following hepatic resection. J Gast Surg 21: 238-248, 2017.

28 Margonis GA, Sasaki K, Andreatos N, Pour MZ, Shao N, Ghasebeh MA, Buettner S, Antoniou E, Wolfgang CL, Weiss M, Kamel IR and Pawlik TM: Increased kinetic growth rate during late phase liver regeneration impacts the risk of tumor recurrence after colorectal liver metastases resection. HPB (Oxford) 19: 808$817,2017$.

29 Adam R, Imai K, Castro Benitez C, Allard MA, Vibert E, Sa Cunha A, Cherqui D, Baba $\mathrm{H}$ and Castaing D: Outcome after associating liver partition and portal vein ligation for staged hepatectomy and conventional two-stage hepatectomy for colorectal liver metastases. Br J Surg 103: 1521-1529, 2016.

30 Hammill CW, Billingsley KG, Cassera MA, Wolf RF, Ujiki MB and Hansen PD: Outcome after laparoscopic radiofrequency ablation of technically resectable colorectal liver metastases. Ann Surg Onc 18: 1947-1954, 2011. 
31 Leung U, Gonen M, Allen PJ, Kingham TP, DeMatteo RP, Jarnagin WR and D'Angelica MI: Colorectal cancer liver metastases and concurrent extrahepatic disease treated with resection. Ann Surg 265: 158-165, 2017.

32 Berber E, Pelley R and Siperstein AE: Predictors of survival after radiofrequency thermal ablation of colorectal cancer metastases to the liver: a prospective study. J Clin Oncol 23: 1358-1364, 2005.

33 Elias D, Baton O, Sideris L, Boige V, Malka D, Liberale G, Pocard $\mathrm{M}$ and Lasser P: Hepatectomy plus intraoperative radiofrequency ablation and chemotherapy to treat technically unresectable multiple colorectal liver metastases. J Surg Onc 90: 36-42, 2005.

34 John SK, Robinson SM, Rehman S, Harrison B, Vallance A, French JJ, Jaques BC, Charnley RM, Manas DM and White SA: Prognostic factors and survival after resection of colorectal liver metastasis in the era of preoperative chemotherapy: an 11-year single-centre study. Dig Surg 30: 293-301, 2013.

35 Karanjia ND, Lordan JT, Fawcett WJ, Quiney N and Worthington TR: Survival and recurrence after neo-adjuvant chemotherapy and liver resection for colorectal metastases: a ten year study. Eur J Surg Oncol 35: 838-843, 2009.
36 Sakamoto Y, Miyamoto Y, Beppu T, Nitta H, Imai K, Hayashi H, Baba Y, Yoshida N, Chikamoto A and Baba H: Postchemotherapeutic CEA and CA19-9 are prognostic factors in patients with colorectal liver metastases treated with hepatic resection after oxaliplatin-based chemotherapy. Anticancer Res 35: 2359-2368, 2015.

37 Sasaki K, Margonis GA, Andreatos N, Wilson A, Gani F, Amini $\mathrm{N}$ and Pawlik TM: Pre-hepatectomy carcinoembryonic antigen (CEA) levels among patients undergoing resection of colorectal liver metastases: do CEA levels still have prognostic implications? HPB (Oxford) 18: 1000-1009, 2016.

Received October 1, 2018

Revised October 10, 2018

Accepted October 11, 2018 